\title{
MINERALISASI NITROGEN KOMPOS CAMPURAN RESIDU KEDELAI DAN JERAMI PADI BERBAGAI KOMPOSISI
}

\author{
Anis Sholihah ${ }^{\mathbf{1}^{\star}}$, Agus Sugianto ${ }^{1}$, M. Taqiudin Alawy ${ }^{1}$ \\ ${ }^{1}$ Departemen Agroteknologi, Fakultas Pertanian Universitas Islam Malang \\ Jl. MT. Haryono No. 193 Malang 65144, Jawa Timur, Indonesia \\ Korespondensi: anis.sholihah@unisma.ac.id
}

\begin{abstract}
Abstrak
Penelitian ini bertujuan mengetahui kualitas kompos dan besarnya pelepasan nitrogen hasil mineralisasi dari kompos campuran residu kedelai dan jerami padi. Penelitian dilakukan dengan dua tahap; Tahap 1. Pembuatan kompos campuran residu kedelai dan jerami padi dengan 5 komposisi campuran yaitu; $D_{1}=100 \%$ residu kedelai; $D_{2}=$ $75 \%$ residu kedelai $+25 \%$ jerami padi; $D_{3}=50 \%$ residu kedelai $+50 \%$ jerami padi; $D_{4}$ $=25 \%$ residu kedelai $+75 \%$ jerami padi; D5 $=100 \%$ jerami padi. Tahap 2 . Percobaan inkubasi tidak tercuci bertujuan mengetahui besarnya mineralisasi nitrogen dari hasil kompos campuran tahap 1 dengan mengukur besarnya nitrogen yang terlepas ke dalam tanah, percobaan menggunakan Rancangan Acak Lengkap (RAL) dengan perlakuan kompos campuran yang sama dengan tahap 1 ditambah 2 perlakuan pembanding yaitu perlakuan kontrol dan perlakuan NPK $\left(D_{6}\right)$. Hasil penelitian menunjukkan campuran bahan organik yang berbeda kualitas residu kedelai dan jerami padi memberikan dinamika mineralisasi $\mathrm{N}$ yang sama dimana mineral $\mathrm{N}$ kumulatif meningkat dengan bertambahnya residu kedelai dalam campuran selama masa inkubasi (1,2,4 dan 8 minggu). Perlakuan $D_{1}$ (residu $100 \%$ kedelai) menunjukkan kecepatan mineralisasi dan jumlah $\mathrm{N}$ yang dilepaskan (mineral $\mathrm{N}$ ) tertinggi berturutturut sebesar 0,0602 $\mathrm{mg} \mathrm{minggu}^{-1}$ dan $1225,39 \mathrm{mg} \mathrm{kg}^{-1}$.
\end{abstract}

Kata kunci: kompos, residu kedelai, jerami padi, mineral N, mineralisasi.

\begin{abstract}
This study aims to determine the quality of the compost and the amount of nitrogen release resulting from mineralization from the compost mixture of soybean residues and rice straw. The research was conducted in two stages; Stage 1. Making a compost mixture of soybean residue and rice straw with 5 mixed compositions, namely; D1 = $100 \%$ soybean residue; D2 $=75 \%$ soybean residue $+25 \%$ rice straw; D3 $=50 \%$ soybean residue $+50 \%$ rice straw; D4 $=25 \%$ soybean residue $+75 \%$ rice straw; D5 = $100 \%$ rice straw. Stage 2. The unwashed incubation experiment aims to determine the amount of nitrogen mineralization from the results of the compost mixture of stage 1 by measuring the amount of nitrogen released into the soil, the experiment uses a completely randomized design (CRD) with the same mixed compost treatment with stage 1 plus 2 comparative treatments, namely control treatment and NPK treatment (D6). The results showed that the mixture of organic matter with different residual qualities of soybean and rice straw gave the same dynamics of $\mathrm{N}$ mineralization where the cumulative $\mathrm{N}$ mineral increased with the increase of soybean residue in the mixture during the incubation period $(1,2,4$ and 8 weeks). Treatment D1 (100\% soybean residue) showed the highest rate of mineralization and the amount of $\mathrm{N}$ released (mineral N) of $0.0602 \mathrm{mg}$ week -1 and $1225.39 \mathrm{mg} \mathrm{kg}-1$, respectively.
\end{abstract}

Key words: compost, soybean residue, rice straw, mineral $\mathrm{N}$, mineralization 


\section{Pendahuluan}

Masukan bahan organik menjadi salah satu cara yang dapat memulihkan kesuburan dan kesehatan tanah. Bahan organik banyak tersedia di sekitar lahan pertanian yang belum termanfaatkan secara optimal antara lain jerami padi dan sisa/residu tanaman kedelai. Jerami merupakan bagian dari tanaman padi yang biasanya oleh petani dibakar atau dijadikan sebagai pakan ternak. Jerami tergolong bahan organik kualitas rendah yang memiliki manfaat yang tidak bisa diremehkan dalam mengembalikan kesuburan tanah karena mengandung selulosa, hemiselulosa, lignin serta protein yang tinggi dan merupakan sumber hara bagi tanaman. Jumlah jerami yang sangat melimpah tidak dimanfaatkan dengan baik oleh petani karena ketidaktahuan petani tentang manfaat dari jerami. Berbeda dengan jerami residu kedelai sedikit lebih baik kualitasnya dan merupakan limbah pertanian yang sangat potensial sebagai pakan ternak dan bahan kompos.

Kualitas bahan organik menentukan kecepatan mineralisasi, kualitas bahan organik didefinisikan sebagai komposisi kimia dari residu tanaman dan merupakan faktor yang kritikal dalam mempengaruhi mineralisasi dan pelepasan unsur hara. Kandungan $\mathrm{N}$ atau $\mathrm{C} / \mathrm{N}$ rasio bahan organik residu tanaman umumnya dinyatakan sebagai faktor penting yang mempengaruhi laju mineralisasi dan pelepasan unsur hara bahan organik (Chen, 2006). Beberapa peneliti melaporkan bahwa kandungan lignin bahan organik lebih mempengaruhi laju mineralisasi bahan organik dibandingkan kandungan $\mathrm{N}$, semakin tinggi kandungan lignin semakin lemah pengaruh $\mathrm{N}$ terhadap proses mineralisasi dan semakin besar jumlah $\mathrm{N}$ yang ditahan dalam residu tanaman selama proses mineralisasi (Kaleeem Abbasi et al., 2015).

Kualitas bahan organik yang beragam terutama kandungan $\mathrm{N}$ akan menentukan jumlah $\mathrm{N}$ yang dilepaskan ke dalam tanah. Nitrogen sendiri adalah salah satu unsur hara yang sangat penting untuk pertumbuhan tanaman, dan pemupukan $\mathrm{N}$ merupakan input energi yang paling penting dalam sistim budidaya tanaman (Whitmore et al., 2000; Zentner et al., 2003). Guna mengoptimalkan efisiensi penggunaan $\mathrm{N}$ oleh tanaman maka pengetahuan tentang pola pelepasan $\mathrm{N}$, akumulasi $\mathrm{N}$ tanaman dan mineralisasi $\mathrm{N}$ dalam tanah sangat dibutuhkan untuk mencegah terjadinya kehilangan $\mathrm{N}$ dari ekosistem. Mengingat unsur $\mathrm{N}$ mudah sekali mengalami perubahan dari satu bentuk ke bentuk yang lainnya tergantung dari proses mineralisasi dan nitrifikasi yang dipengaruhi pula oleh kondisi lingkungan seperti suhu, kelembaban (Rathke et al., 2006), sifat tanah ( $\mathrm{pH}$, tekstur, kandungan bahan organik) dan kualitas bahan organik itu sendiri; rasio $\mathrm{C} / \mathrm{N}$, lignin, polifenol dan ukuran partikel (Van Kessel \& Reeves, 2002; Stadler et al., 2006). 
Kualitas bahan organik dapat dimanipulasi dengan berbagai cara salah satunya dengan percampuran kualitas rendah dan kualitas tinggi pada berbagai komposisi sehingga akan didapatkan bahan organik yang bervariasi kualitasnya. Manipulasi kualitas dilakukan pada dua jenis bahan organik yang berbeda yaitu jerami padi dan residu kedelai.yang selanjutnya diaplikasikan ke dalam tanah dan diukur kecepatan mineralisasinya. Penelitian ini bertujuan mengetahui kualitas kompos dan besarnya pelepasan nitrogen hasil mineralisasi dari kompos campuran residu kedelai dan jerami padi. 


\section{Bahan dan Metode}

Penelitian dilaksanakan pada bulan Pebruari sampai Juli 2020 di Rumah Desa Losari Kecamatan Singosari Kota Malang yang terletak pada $137,35^{\circ} \mathrm{LU}$ dan $7,5^{\circ} \mathrm{LS}$ ketinggian $\pm 500 \mathrm{mdpl}$, suhu pada siang hari $24-28^{\circ} \mathrm{C}$ dan pada malam hari suhu berkisar antara $16-21^{\circ} \mathrm{C}$, kelembapan relatif malam hari mencapai 95\% dan pada siang hari berkisar $79 \%$, curah hujan rata-rata mencapai $167,6 \mathrm{~mm} /$ hari. Analisis tanah dilakukan di Laboratorium Kimia Tanah Jurusan Tanah Fakultas Pertanian Universitas Brawijaya dan pembuatan kompos dilaksanakan di Laboratorium vermikompos Fakultas Pertanian Universitas Islam Malang. Penelitian dilakukan 2 tahapan sebagai berikut: Tahap 1. Pembuatan kompos campuran residu kedelai dan jerami padi, alat dan bahan yang digunakan antara lain : terpal, karung, gunting, ember, timbangan digital, pengaduk kayu, garu, EM4, urea, air, residu dan jerami padi. Terdapat 5 kompos campuran yaitu; $D_{1}=100 \%$ residu kedelai; $D_{2}=75 \%$ residu kedelai $+25 \%$ jerami padi; $D_{3}=50 \%$ residu kedelai $+50 \%$ jerami padi; $D_{4}=25 \%$ residu kedelai + $75 \%$ jerami padi; D5 = 100\% jerami padi. Tahap ini memerlukan waktu $15-20$ hari, setelah kompos matang dianalisis kualitasnya meliputi; kandungan $\mathrm{N}$ total (\%), $\mathrm{C} / \mathrm{N}$ rasio, $\mathrm{P}_{2} \mathrm{O}_{5}(\mathrm{~g} / 100), \mathrm{K}_{2} \mathrm{O}(\mathrm{g} / 100)$, C-Organik (\%), Lignin (\%), polifenol (\%), Selulosa (\%), Polifenol/N dan Lignin/N. Tahap 2. Percobaan inkubasi tidak tercuci, alat dan bahan yang digunakan antara lain : gelas plastik ukuran $250 \mathrm{ml}$, timbangan digital, sendok, tanah, campuran kompos brangkasan kedelai dan jerami padi yang sudah matang. Percobaan ini dirancang menggunakan Rancangan Acak Lengkap sederhana dengan 5 perlakuan kompos hasil tahap 1 ditambah 2 perlakuan pembanding yaitu perlakuan kontrol dan perlakuan NPK $\left(D_{6}\right)$ dengan 3 ulangan dan 5 sampel. Percobaan menggunakan gelas plastik ukuran $250 \mathrm{ml}$ diisi dengan tanah $400 \mathrm{~g}$ jenis Inseptisol (Soil Survey Staff, 2014) ditambah $4 \mathrm{~g}$ campuran kompos hasil percobaan tahap 1 (setara dosis 20 ton ha ${ }^{-1}$ ), selanjutnya ditambah air sampai kondisi kapasitas lapang. Pengamatan amonium dan nitrat (mineral $\mathrm{N}$ ) dilakukan pada umur inkubasi 1, 2 , 4 dan 8 minggu. Pada umur pengamatan tersebut dilakukan perhitungan konstanta kecepatan mineralisasi $\mathrm{N}\left(\mathrm{kN}\right.$, minggu $\left.^{-1}\right)$ dengan metode (Wieder \& Lang, 1982) dengan persamaan :

$$
Y=\exp ^{(-k t)}
$$

Dimana : $\mathrm{Y}=$ jumlah $\mathrm{N}$ residu tanaman yang tersisa (\%) pada waktu ' $\mathrm{t}$ ', $\mathrm{T}=$ waktu (minggu). Dari perhitungan tersebut didapatkan persamaan regresi dimana ' $Y$ ' merupakan 'In' sisa dan nilai 'k' merupakan slope. Data hasil percobaan dianalisis dengan menggunakan analisis ragam (uji $\mathrm{F}$ ) dengan taraf $5 \%$ untuk mengetahui 
pengaruh perlakuan dan dilanjutkan dengan uji BNJ 5\% apabila pengaruh perlakuan nyata.

\section{Hasil dan Pembahasan}

\section{Kualitas Kompos Campuran Residu Kedelai dan Jerami Padi}

Hasil analisis kualitas kompos brangkasan kedelai dan jerami padi terlihat pada Tabel 1, menunjukkan kandungan $\mathrm{N}$, kandungan $\mathrm{P}_{2} \mathrm{O}$ dan $\mathrm{K}_{2} \mathrm{O}$ menurun dengan makin menurunnya kandungan residu kedelai dalam campuran sebaliknya rasio $\mathrm{C} / \mathrm{N}$, kandungan lignin, polifenol, selulose, rasio polifenol/ $\mathrm{N}$ dan rasio lignin/ $\mathrm{N}$ meningkat dengan makin menurunnya kandungan brangkasan kedelai dalam campuran.

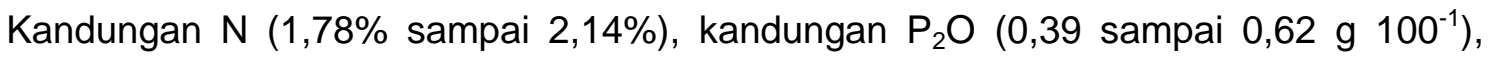
kandungan $\mathrm{K}_{2} \mathrm{O}$ (0,62 sampai $\left.1,35 \mathrm{~g} 100^{-1}\right)$, C/N rasio (19,03 sampai 26,70), kandungan polifenol (1,14 sampai 2,84$)$, kandungan lignin $(7,24$ sampai 34,32$)$, kandungan selulose $(15,34$ sampai 36,38$)$, polifenol/ $\mathrm{N}$ rasio $(0,53$ sampai 1,59$)$ dan lignin/ $\mathrm{N}$ rasio (3,38 sampai 19,27).

Tabel 1. Kualitas kompos campuran residu kedelai dan jerami padi

\begin{tabular}{cccccccccc}
\hline $\begin{array}{c}\text { Campuran } \\
\text { Kompos }\end{array}$ & $\begin{array}{c}\mathrm{N} \text { total } \\
(\%)\end{array}$ & $\begin{array}{c}\mathrm{C} / \mathrm{N} \\
\text { rasio }\end{array}$ & $\begin{array}{c}\mathrm{P}_{2} \mathrm{O} \\
\left(\mathrm{g} 100^{-1}\right)\end{array}$ & $\begin{array}{c}\mathrm{K}_{2} \mathrm{O} \\
\left(\mathrm{g} 100^{-1}\right)\end{array}$ & $\begin{array}{c}\text { Polifenol } \\
(\%)\end{array}$ & $\begin{array}{c}\text { Lignin } \\
(\%)\end{array}$ & $\begin{array}{c}\text { Selulose } \\
(\%)\end{array}$ & Polifenol/N & Lignin/N \\
\hline $\mathrm{D}_{1}$ & 2,14 & 19,03 & 0,62 & 1,35 & 1,14 & 7,24 & 15,34 & 0,53 & 3,38 \\
$\mathrm{D}_{2}$ & 2,06 & 27,74 & 0,59 & 1,28 & 1,57 & 9,02 & 17,22 & 0,76 & 4,37 \\
$\mathrm{D}_{3}$ & 1,98 & 26,78 & 0,47 & 1,23 & 2,14 & 13,72 & 22,39 & 1,08 & 6,93 \\
$\mathrm{D}_{4}$ & 1,87 & 26,13 & 0,42 & 1,10 & 2,57 & 24,63 & 27,83 & 1,37 & 13,19 \\
$\mathrm{D}_{5}$ & 1,78 & 26,70 & 0,39 & 0,62 & 2,84 & 34,32 & 36,38 & 1,59 & 19,27 \\
\hline
\end{tabular}

Pada penelitian ini didapatkan hasil analisa kualitas kompos campuran residu kedelai dan jerami padi bervariasi. Kualitas kompos merupakan prediksi terbaik untuk mengontrol pelepasan $\mathrm{N}$ di bawah kondisi tidak tercuci. Diperkuat oleh penelitian (Thippayarugs et al., 2008) yang menemukan koefisien tertinggi (81.7\%) antara kandungan $\mathrm{N}$ dengan jumlah mineral $\mathrm{N}$ setelah inkubasi 133 hari. Residu tanaman dengan rasio $\mathrm{C} / \mathrm{N}$, lignin dan polifenol yang tinggi akan melepaskan $\mathrm{N}$ dengan lambat (Achakzai \& Bangulzai, 2006).

\section{Mineralisasi N Campuran Kompos}

Jumlah $\mathrm{N}$ yang dilepaskan kompos setelah diaplikasikan ke dalam tanah dalam percobaan inkubasi meningkat dengan makin meningkatnya residu kedelai dalam campuran (Tabel 2). Perlakuan kompos campuran $\mathrm{D}_{1}$ menunjukkan $\mathrm{N}$ yang dilepaskan tertinggi dibanding perlakuan kompos lain selama inkubasi berturut-turut sebesar $185,62 \mathrm{mg} \mathrm{kg}^{-1}, 376,66 \mathrm{mg} \mathrm{kg}^{-1}, 679,09$ dan 1225,39 $\mathrm{mg} \mathrm{kg}^{-1}$ hal ini sejalan dengan 
nilai kecepatan mineralisasi tertinggi ditunjukkan perlakuan $D_{1}$ sebesar $0,0602 \mathrm{mg}$ minggu $^{-1}$ (Tabel 2). Selama inkubasi perlakuan kontrol melepaskan $\mathrm{N}$ terendah hal ini menunjukkan bahwa penambahan kompos campuran sisa kedelai dan jerami padi dapat meningkatkan $81,09 \%$ sampai 123,01 jumlah mineral $\mathrm{N}$ dalam tanah. Kandungan $\mathrm{N}$ dalam kompos menentukan jumlah $\mathrm{N}$ yang terlepas ke dalam tanah, dimana kandungan $\mathrm{N}$ kompos meningkat dengan meningkatnya residu kedelai yang diberikan dalam tanah karena residu kedelai mengandung $\mathrm{N}$ paling tinggi disamping dipengaruhi juga oleh parameter kualitas yang lain.

Tabel 2. Kecepatan mineral $\mathrm{n}$ dan mineral $\mathrm{n}$ kumulatif $\left(\mathrm{mg} \mathrm{kg}^{-1}\right)$ campuran kompos residu kedelai dan jerami padi

\begin{tabular}{|c|c|c|c|c|c|c|c|c|c|}
\hline \multirow{3}{*}{$\begin{array}{l}\text { Perlakuan } \\
\text { Kontrol }\end{array}$} & \multicolumn{8}{|c|}{ Mineral N Kumulatif $\left(\mathrm{mg} \mathrm{pot}^{-1}\right)$} & \multirow{3}{*}{$\begin{array}{c}\text { Kecepatan } \\
\text { mineralisasi } \mathrm{N}, \\
\mathrm{kN} \\
\left(\mathrm{mg} \mathrm{minggu}^{-1}\right) \\
--\end{array}$} \\
\hline & \multicolumn{2}{|c|}{ Minggu 1} & \multicolumn{2}{|c|}{ Minggu 2} & \multicolumn{2}{|c|}{ Minggu 4} & \multicolumn{2}{|c|}{ Minggu 8} & \\
\hline & 80,16 & a & 157,99 & a & 316,14 & a & 591,18 & a & \\
\hline $\mathrm{D}_{1}$ & 185,62 & $d$ & 376,66 & g & 679,09 & c & 1225,39 & e & 0,0602 \\
\hline$D_{2}$ & 164,33 & c & 343,62 & e & 565,98 & $b$ & 1162,56 & cde & 0,0593 \\
\hline$D_{3}$ & 151,40 & $\mathrm{~b}$ & 320,34 & $d$ & 654,09 & c & 1023,71 & bcd & 0,0509 \\
\hline $\mathrm{D}_{4}$ & 145,20 & $b$ & 302,89 & c & 660,96 & c & 988,68 & bc & 0,0483 \\
\hline$D_{5}$ & 143,59 & $d$ & 288,07 & $b$ & 637,46 & bc & 922,12 & $b$ & 0,0503 \\
\hline $\mathrm{D}_{6}$ & 178,21 & $d$ & 360,69 & $f$ & 717,31 & $\mathrm{c}$ & 1186,48 & de & - \\
\hline BNJ 5\% & \multicolumn{2}{|l|}{9,64} & \multicolumn{2}{|c|}{8,74} & \multicolumn{2}{|c|}{81,62} & \multicolumn{2}{|c|}{183,14} & \\
\hline
\end{tabular}

Mineralisasi, dekomposisi dan nitrifikasi merupakan proses-proses yang sangat penting dalam tanah yang dikontrol oleh kelembaban, temperature dan kualitas bahan organik tersebut (Silver \& Miya, 2001; Núñez et al., 2001). Adanya perbedaan jumlah N mineral yang dilepaskan campuran kompos disamping parameter kualitas di atas juga karena adanya besarnya keragaman meskipun dalam spesies tanaman, morfologi jaringan tanaman dapat memainkan peranan penting (Annoussamy et al., 2000) dalam menentukan kualitas residu tanaman. Parameter $\mathrm{C} / \mathrm{N}$ merupakan parameter yang paling banyak digunakan untuk mengontrol proses mineralisasi dan immobilisasi $\mathrm{N}$ (Trinsoutrot et al., 2000), disamping itu faktor-faktor yang lain seperti kandungan $\mathrm{N}$ (Cogle et al., 1989), polifenol (Chaves et al., 2005), dan lignin (Hofmann et al., 2009)

Margna, (1977) mengatakan apabila kandungan nutrisi dalam tanah kekurangan akan menyebabkan peningkatan aktifitas enzim phenylalanine ammonialyase yang merupakan enzim untuk sintesis polifenol. Pada saat kekurangan $\mathrm{N}$, phenylalanine memanfaatkan $\mathrm{N}$ untuk berubah menjadi bentuk senyawa fenol yang lebih komplek. Ditambah lagi sintesis protein yang lambat pada kondisi $\mathrm{N}$ yang terbatas sehingga karbohidrat tidak dapat dipakai untuk sintesis fenol. 
Jumlah mineral $\mathrm{N}$ yang dilepaskan secara konsisten $100 \%$ residu kedelai $\left(D_{1}\right)$ lebih tinggi dibanding lainnya selanjutnya menurun dengan makin berkurangnya residu kedelai dalam campuran, hal ini sejalan dengan penelitian yang dilakukan (Lemus et al., 2008) adanya peningkatan jumlah mineral $\mathrm{N}$ tanah karena adanya pemberian pupuk $\mathrm{N}$ dalam bentuk urea pada media tanaman sejenis rumput dengan berbagai dosis aplikasi. Pada penelitian ini saat pengamatan (minggu 1 sampai minggu 8) persentase peningkatan jumlah mineral $\mathrm{N}$ dari minggu 1 ke minggu 2 paling tinggi (104,99\%) dan selanjutnya makin menurun menuju minggu 4 dan minggu 8 berturutturut sebesar $98,13 \%$ dan $70,23 \%$. Hal tersebut menunjukkan bahwa residu kedelai merupakan residu kualitas tinggi (Tabel 1) dibanding jerami padi. Kandungan $\mathrm{N}$ residu kedelai lebih tinggi dari jerami padi dan kandungan polifenol, lignin, rasio lignin: $\mathrm{N}$, rasio polifenol: $\mathrm{N}$ dan rasio (lignin+polifenol): $\mathrm{N}$ residu kedelai lebih rendah dari jerami padi.

Tabel 3. Koefisien determinasi regresi linier parameter kualitas campuran kompos residu kedelai dan jerami padi dengan \%N yang dilepaskan sebagai mineral $\mathrm{n}$ dalam tanah

\begin{tabular}{|c|c|c|c|c|c|}
\hline \multirow{3}{*}{$\begin{array}{c}\text { Paremeter } \\
\text { Kualitas Kompos }\end{array}$} & \multicolumn{4}{|c|}{ Koefisien Determinasi $\left(\mathrm{R}^{2}\right)$} & \multirow{3}{*}{$\begin{array}{c}\text { Konstanta } \\
\text { kecepatan } \\
\text { mineralisasi } \mathrm{N}, \mathrm{kN} \\
\left(\mathrm{mg} \mathrm{minggu}^{-1}\right)\end{array}$} \\
\hline & \multicolumn{4}{|c|}{ Mineral $\mathrm{N}$ tanah $\left(\mathrm{mg} \mathrm{kg}^{-1}\right)$} & \\
\hline & Minggu 1 & Minggu 2 & Minggu 4 & Minggu 8 & \\
\hline $\mathrm{N}$ total $(\%)$ & $0,8003^{* *}$ & $0,9538^{* *}$ & 0,0785 tn & $0,7473^{* *}$ & $0,8682^{* *}$ \\
\hline $\mathrm{C} / \mathrm{N}$ rasio & 0,1690 tn & $0,2442 \mathrm{tn}$ & $0,0241 \mathrm{tn}$ & $0,1334 \mathrm{tn}$ & 0,2692 tn \\
\hline $\mathrm{P}_{2} \mathrm{O}(\mathrm{g} \mathrm{100-1)}$ & $0,8198^{* *}$ & 0,9520 ** & 0,0834 tn & $0,8008^{* *}$ & 0,8862 ** \\
\hline $\mathrm{K}_{2} \mathrm{O}(\mathrm{g} 100-1)$ & 0,4111 * & $0,5337^{* *}$ & 0,1040 tn & 0,4254 * & 0,7830 ** \\
\hline Polifenol (\%) & $0,8500^{* *}$ & $0,9506^{* *}$ & 0,0945 tn & 0,8332 ** & $0,9048^{* \star}$ \\
\hline Lignin (\%) & 0,6722 ** & 0,9319 ** & 0,1045 tn & 0,6626 ** & $0,9441^{\star \star}$ \\
\hline Selulose (\%) & $0,7033^{* *}$ & $0,9394^{* *}$ & 0,1173 tn & $0,7275^{* *}$ & $0,9755^{* *}$ \\
\hline Polifenol/N & 0,8239 ** & $0,9537^{* *}$ & 0,0978 tn & $0,8065^{* *}$ & $0,9149 * *$ \\
\hline Lignin/N & $0,6577^{* \star}$ & $0,9286^{* *}$ & 0,1054 tn & $0,6503^{* *}$ & $0,9350^{\star \star}$ \\
\hline
\end{tabular}

Keterangan :* Nyata pada uji regresi $5 \%$; ${ }^{* *}$ Nyata pada uji regresi $1 \%$; tn $=$ tidak nyata uji regresi $5 \%$; \& $1 \%$.

Analisis regresi linier guna melihat hubungan dan pengaruh lingkungan antara parameter kualitas kompos dengan jumlah minerah $\mathrm{N}$ dan kecepatan mineralisasi terlihat pada Tabel 3, didapatkan bahwa parameter kualitas berpengaruh nyata pada $P$ $<0,01$ dan $\mathrm{P}<0,05$ selama inkubasi dengan jumlah mineral $\mathrm{N}$ yang dilepaskan kecuali pada minggu ke 4. Demikian juga terhadap kecepatan mineralisasi $\mathrm{N}$ parameter kualitas berpengaruh nyata kecuali pada $\mathrm{C} / \mathrm{N}$ rasio. Koefisien determinasi tertinggi pada minggu 1 dan 8 ditunjukkan oleh parameter kandungan polifenol sebesar $85 \%$ dan 83,32\%, minggu 2 parameter kandungan $\mathrm{N}$ sebesar 95,38\%. Analisis regresi menunjukkan hubungan yang signifikan antara kecepatan pelepasan $N(k N)$ dan parameter kualitas kompos seperti $\mathrm{N}$, kandungan $\mathrm{P}_{2} \mathrm{O}, \mathrm{K}_{2} \mathrm{O}$, polifenol, lignin, selulose, polifenol/ $\mathrm{N}$ dan lignin/ $\mathrm{N}$ kecuali $\mathrm{C} / \mathrm{N}$. Hubungan tertinggi kecepatan mineralisasi $\mathrm{N}$ 
parameter selulose sebesar 97,55\%, hal ini menunjukkan pentingnya parameter tersebut untuk memprediksi pelepasan $\mathrm{N}$ dari residu tanaman, karena aktifitas mikroba tanah dan proses mineralisasi dipengaruhi oleh kandungan lignin, polifenol dan senyata larut $\mathrm{N}$ dan $\mathrm{C}$ dalam bahan organik yang ditambahkan (Palm et al., 2001; Bolger et al., 2003). Beberapa peneliti mengatakan apabila nilai $\mathrm{C} / \mathrm{N}$ rasio diatas 25 maka akan berpotensi meningkatkan immobilisasi N dalam tanah (Hadas et al., 1992; Sainju et al., 2005; Muhammad et al., 2011). Pada penelitian ini terlihat bahwa semua kompos campuran mempunyai kandungan $\mathrm{N}$ cukup tinggi yakni lebih besar dari $1.75 \%$ sehingga dimungkinkan kecepatan mineralisasi berjalan cukup cepat. (Handayanto \& Sholihah, 2010) mengatakan bahwa kecepatan mineralisasi $\mathrm{N}$ dari pangkasan tanaman legume yang bervariasi dipengaruhi signifikan oleh kandungan $\mathrm{N}$, lignin, polifenol dan selulose pangkasan, dimana pelepasan $\mathrm{N}$ meningkat dengan meningkatnya kandungan $\mathrm{N}$ dan menurun dengan menurunnya kandungan polifenol, selulose dan lignin. Dalam penelitian ini dibuktikan juga besarnya koefisien determinasi antara parameter kualitas residu dengan kecepatan mineralisasi $\mathrm{N}$ dengan besarnya koefisien determinasi paling tinggi pada selulose $(97,55 \%)$ selanjutnya diikuti kandungan lignin $(94,41 \%)$, rasio lignin/N $(93,5 \%)$, rasio polifenol/N $(91,49 \%)$, polifenol $(90,48 \%)$ dan kandungan $\mathrm{N}(86,82)$, hal tersebut menunjukkan bahwa kualitas kompos merupakan prediksi terbaik untuk mengontrol pelepasan $\mathrm{N}$ dibawah kondisi tidak tercuci.

Hasil penelitian menunjukkan campuran residu kualitas tinggi dengan kualitas rendah dapat meningkatkan residu kualitas rendah terbukti dengan makin meningkatkan kandungan $\mathrm{N}(5,06-20,22 \%), \mathrm{P}_{2} \mathrm{O}(7,69-58,97 \%), \mathrm{K}_{2} \mathrm{O}(77,42-$ $117,74 \%)$ dan menurunkan $\mathrm{C} / \mathrm{N}(2,13-28,73 \%)$, kandungan polifenol $(9,51-59,86 \%)$, lignin $(28,23-78,90 \%)$, selulose $(23,50-57,83 \%)$, rasio polifenol/N (13,84 - 31,55\%) dan lignin/N (66,67 - 82,46\%) sehingga mempercepat mineralisasi residu tanaman kualitas rendah sejalan dengan penelitian yang dilakukan Tanahashi et al. (2004), karena kualitas residu dapat merubah aktifitas mikroba dan menyeimbangkan proses mineralisasi dan immobilisasi N (Gentile et al., 2009). 


\section{Kesimpulan dan Saran}

\section{Kesimpulan}

1. Adanya peningkatan kualitas kompos jerami padi (kualitas rendah) sebesar $N(5,06$ - 20,22\%), $\mathrm{P}_{2} \mathrm{O}(7,69-58,97 \%), \mathrm{K}_{2} \mathrm{O}(77,42-117,74 \%)$ dan penurunan $\mathrm{C} / \mathrm{N}(2,13$ $28,73 \%)$, kandungan polifenol $(9,51-59,86 \%)$, lignin $(28,23-78,90 \%)$, selulose $(23,50-57,83 \%)$, rasio polifenol/N (13,84 - 31,55\%) dan lignin/N (66,67 - 82,46\%) setelah dicampur dengan residu kedelai (kualitas tinggi).

2. Perlakuan $D_{1}$ (residu $100 \%$ kedelai) menunjukkan kecepatan mineralisasi dan jumlah $\mathrm{N}$ yang dilepaskan (mineral $\mathrm{N}$ ) tertinggi berturut-turut sebesar $0,0602 \mathrm{mg}$ minggu ${ }^{-1}$ dan $1225,39 \mathrm{mg} \mathrm{kg}^{-1}$.

3. Parameter kualitas kompos yang paling berpengaruh terhadap jumlah mineral $\mathrm{N}$ adalah kandungan polifenol dengan koefisien determinasi $84,16 \%$ dan terhadap kecepatan mineralisasi $\mathrm{N}$ parameter selulose sebesar 97,55\% (koefisien determinasi).

\section{Saran}

Penelitian lanjut perlu dilakukan pengaruh faktor lingkungan terhadap mineralisasi $\mathrm{N}$

\section{Ucapan Terimakasih}

Peneliti mengucapkan terimakasih banyak kepada Kemenristek yang telah mendanai penelitian ini melalui skim PTUPT tahun 2020.

\section{DAFTAR PUSTAKA}

Achakzai, A.K.K. and Bangulzai, M.I., 2006. Effect of various levels of nitrogen fertilizer on the yield and yield attributes of pea (Pisum sativum L.) cultivars. Pakistan Journal of Botany, 38(2), p.331.

Annoussamy, M., Richard, G., Recous, S. and Guerif, J., 2000. Change in mechanical properties of wheat straw due to decomposition and moisture. Applied Engineering in Agriculture, 16(6), p.657.

Bolger, T.P., Angus, J.F. and Peoples, M.B. 2003. Comparison of nitrogen mineralisation patterns from root residues of Trifolium subterraneum and Medicago sativa. Biology and Fertility of soils, 38(5), pp.296-300.

Chaves, B., De Neve, S., Boeckx, P., Van Cleemput, O. and Hofman, G. 2005. Screening organic biological wastes for their potential to manipulate the $\mathrm{N}$ release from $\mathrm{N}$-rich vegetable crop residues in soil. Agriculture, ecosystems \& environment, 111(1-4), 81-92.

Chen, J.H., 2006, October. The combined use of chemical and organic fertilizers and/or biofertilizer for crop growth and soil fertility. In International workshop on sustained management of the soil-rhizosphere system for efficient crop production and fertilizer use, 16(20), 1-11. Land Development Department 
Bangkok Thailand.

Cogle, A. L., Saffigna, P. G., and Strong, W. M. 1989. Carbon transformations during wheat straw decomposition. Soil Biology and Biochemistry, 21(3), 367-372.

Gentile, R., Vanlauwe, B., Van Kessel, C., and Six, J. 2009. Managing N availability and losses by combining fertilizer- $\mathrm{N}$ with different quality residues in Kenya. Agriculture, ecosystems \& environment, 131(3-4), 308-314.

Hadas, A., Feigenbaum, S., Molina, J. A. E., and Clapp, C. E. 1992. Factors affecting nitrogen immobilization in soil as estimated by simulation models. Soil Science Society of America Journal, 56(5), 1481-1486.

Handayanto, E., \& Sholihah, A. 2010. Nitrogen mineralization by maize from previously added legume residues following addition of new legume residues using $15 \mathrm{~N}$ labelling technique. Journal of Tropical Agriculture, 48(2), 23-27.

Hofmann, A., Heim, A., Christensen, B. T., Miltner, A., Gehre, M., and Schmidt, M. W. I. 2009. Lignin dynamics in two 13C-labelled arable soils during 18 years. European Journal of Soil Science, 60(2), 250-257.

Kaleeem Abbasi, M., Mahmood Tahir, M., Sabir, N., and Khurshid, M. 2015. Impact of the addition of different plant residues on nitrogen mineralization-immobilization turnover and carbon content of a soil incubated under laboratory conditions. Solid Earth, 6(1), 197-205.

Lemus, R., Parrish, D. J., and Abaye, O. 2008. Nitrogen-use dynamics in switchgrass grown for biomass. Bioenergy Research, 1(2), 153-162.

Margna, U. 1977. Control at the level of substrate supply-an alternative in the regulation of phenylpropanoid accumulation in plant cells. Phytochemistry, 16(4), 419-426.

Muhammad, W., Vaughan, S. M., Dalal, R. C., and Menzies, N. W. 2011. Crop residues and fertilizer nitrogen influence residue decomposition and nitrous oxide emission from a Vertisol. Biology and Fertility of Soils, 47(1), 15-23.

Núñez, S., Martínez-Yrízar, A., Búrquez, A., and García-Oliva, F. 2001. Carbon mineralization in the southern Sonoran Desert. Acta Oecologica, 22(5-6), 269276.

Palm, C. A., Gachengo, C. N., Delve, R. J., Cadisch, G., and Giller, K. E. 2001. Organic inputs for soil fertility management in tropical agroecosystems: application of an organic resource database. Agriculture, ecosystems \& environment, 83(1-2), 27-42.

Rathke, G. W., Behrens, T., and Diepenbrock, W. 2006. Integrated nitrogen management strategies to improve seed yield, oil content and nitrogen efficiency of winter oilseed rape (Brassica napus L.): a review. Agriculture, ecosystems \& environment, 117(2-3), 80-108.

Sainju, U. M., Whitehead, W. F., and Singh, B. P. 2005. Carbon accumulation in cotton, sorghum, and underlying soil as influenced by tillage, cover crops, and nitrogen fertilization. Plant and Soil, 273(1), 219-234.

Silver, W. L., and Miya, R. K. 2001. Global patterns in root decomposition: comparisons of climate and litter quality effects. Oecologia, 129(3), 407-419.

Soil Survey Staff. 2014. Keys to soil taxonomy. Soil Conservation Service.

Stadler, C., Von Tucher, S., Schmidhalter, U., Gutser, R., and Heuwinkel, H. 2006. 
Nitrogen release from plant-derived and industrially processed organic fertilizers used in organic horticulture. Journal of plant nutrition and soil science, 169(4), 549-556.

Tanahashi, T., Murase, J., Matsuya, K., Asakawa, S., and Kimura, M. 2004. Microbial communities responsible for the decomposition of rice straw compost in a Japanese rice paddy field determined by phospholipid fatty acid (PLFA) analysis. Soil science and plant nutrition, 50(8), 1229-1236.

Thippayarugs, S., Toomsan, B., Vityakon, P., Limpinuntana, V., Patanothai, A., and Cadisch, G. 2008. Interactions in decomposition and $\mathrm{N}$ mineralization between tropical legume residue components. Agroforestry Systems, 72(2), 137-148.

Trinsoutrot, I., Recous, S., Bentz, B., Linères, M., Chèneby, D., and Nicolardot, B. 2000. Biochemical quality of crop residues and carbon and nitrogen mineralization kinetics under nonlimiting nitrogen conditions. Soil Science Society of America Journal, 64(3), 918-926.

Van Kessel, J. S., and Reeves, J. 2002. Nitrogen mineralization potential of dairy manures and its relationship to composition. Biology and Fertility of Soils, 36(2), 118-123.

Whitmore, A. P., Cadisch, G., Toomsan, B., Limpinuntana, V., Van Noordwijk, M., and Purnomosidhi, P. 2000. An analysis of the economic values of novel cropping systems in NE Thailand and S. Sumatra. NJAS-Wageningen Journal of Life Sciences, 48(1), 105-114.

Wider, R. K., and Lang, G. E. 1982. A critique of the analytical methods used in examining decomposition data obtained from litter bags. Ecology, 63(6), 16361642.

Zentner, R.P., Campbell, C.A., Selles, F., McConkey, B.G., Jefferson, P.G. and Lemke, R. 2003. Cropping frequency, wheat classes and flexible rotations: Effects on production, nitrogen economy, and water use in a Brown Chernozem. Canadian Journal of Plant Science, 83(4), 667-680. 